\title{
CHEMICAL STABILITY OF WATER IN THE WATER SUPPLY NETWORK - PRELIMINARY RESEARCH
}

\author{
Ewelina PŁUCIENNIK-KOROPCZUK ${ }^{1}$, Patrycja KUMANOWSKA ${ }^{2}$ \\ University of Zielona Góra, Poland
}

\begin{abstract}
The article presents the results of research on changes in selected water parameters during distribution in the water supply network of the city of 22 thousand inhabitants. Water parameters were controlled at 8 points in the network, distant from Water Treatment Plant from 0.4 to $3.1 \mathrm{~km}$. The location of control points was selected in order to assess the water quality depending on the pipe material and at unfavourable points - at the ends of the network. It was shown that as a result of secondary water contamination an increase in turbidity, colour and total iron occurred. The distance from the Water Treatment Plant and the type of material of the network or connection, affect the quality of the water. It was confirmed that at the ends of the network the water parameters were increased and exceeded the admissible values.
\end{abstract}

Keywords: secondary contamination of water, water supply network, water quality

\section{INTRODUCTION}

The priority of each Water Supply Company is to ensure continuity of production, distribution and delivery of water under appropriate pressure, with the required efficiency and the best possible bacteriological and physico-chemical

${ }^{1}$ Corresponding author: University of Zielona Góra, Institute of Environmental Engineering, Szafrana st. 15, 65-246 Zielona Góra, Poland, e-mail: e.pluciennik@iis.uz.zgora.pl, tel. $+48683282560$

${ }^{2}$ Student of the University of Zielona Góra, Zielona Góra, Poland 
parameters. Often, however, despite the high efficiency of water purification processes, which guarantees the right quality of water at the outlet from the water treatment plant, it is subject to secondary pollution in the distribution system. Access to safe drinking water is a fundamental human right and essential for health protection. Therefore, the prevention of water pollution and the maintenance of sanitary safety of water in the distribution system is currently one of the main objectives of the World Health Organisation [13]. Too little attention paid to the proper management of distribution systems poses several risks favouring secondary pollution of water during its transmission to consumers. A properly working drinking water distribution system should ensure not only proper parameters of quality of water entering the water supply system, but above all at the recipient's premises.

The water distribution system is a complex reactor in which physical, chemical and biological processes can take place, changing the physico-chemical and bacteriological constitution of water [11]. The main reasons of secondary water pollution are:

- lack of chemical and biological stability of the water fed into the network;

- absence or insufficient quantity of disinfectant in water;

- variable, often improper hydraulic conditions when distributing water to consumers;

- damage to pipes and faulty repair;

- changes resulting from the mixing of water from different water intakes (the problem concerns mainly larger cities supplied from several intakes);

- low velocities of water flow in the conditions of rural waterworks,

- inadequate exploitation and maintenance of the network $[1,11]$.

Mentioned factors can be divided into groups connected with water, network's hydraulic, period and quantity of exploitation, material and sealing of pipes and network's structure. Secondary water pollution is usually the result of these factors and it is difficult to determine the role of each of them, especially when often one factor implicates changes of quality in many others impact areas [2].

The European Drinking Water Directive 98/83/EC and Polish regulations (Journal of Laws 2017, item 2294) on the quality of water intended for human consumption established that turbidity should be less than 1 NTU for an effective disinfection in the system. In addition, turbidity values above 5 NTUs can give colour to the water. Metal concentrations are positively correlated with turbidity and increased when turbidity levels are higher. Corrosion of cast iron pipes promotes the accumulation of iron particles in the system. Furthermore, metals are used as coagulants in Water Treatment Plant to eliminate organic matter and residual concentrations of these can enter the distribution system and deposit on the pipes. 
The excessive presence of these metals in potable water can result in discoloured water and/or changes in taste [3].

\section{Chemical stability of water}

Chemical and microbiological stability of water in distribution systems is affected by the raw water quality $[4,7]$ and reliability of treatment processes. The problem is not the quality of water entering the network, because it must meet the parameters of the Regulation of the Minister of Health [10]. The main problem of all water supply systems is the loss of water stability during the transmission from Water Treatment Plant to customer [6,11].

Water is considered as chemically stable when it does not cause the precipitation of deposits, mainly calcium carbonate $\left(\mathrm{CaCO}_{3}\right)$ [11]. The main indicators of contamination for chemically unstable water in the water distribution system are total iron and related turbidity, colour and the use of free chlorine [12].

Ensuring the carbonate-calcium balance of water eliminates its incrustation properties and destroying e.g. cement linings, but only reduces electrochemical corrosion of metals, the course of which is also determined by the content of dissolved oxygen and other oxidizers and dissolved substances, as well as temperature $[11,12]$.

\section{Microbiological stability}

Biologically stable water does not support microbial growth. This is connected with the lack of organic and inorganic nutrients enabling microbial growth [6,11]. The destruction of plant materials is intensified by enzymes that acidify the aquatic environment. Among the effects of chemical instability of water, electrochemical corrosion of metals plays the most important role in the formation and development of biofilm. Its influence, depending on the type of metal being corroded, may stimulate or delay the formation of biological growth. The first situation occurs when the corrosion products are not toxic to microorganisms, and the second situation in the opposite case. Materials whose components constitute a source of nutrients during their initial life cycle facilitate the formation of biofilm [12].

Biofilm can be inhabited by water pipes made of traditional materials such as cast iron and steel or cement, as well as plastics that replace them. Pipelines made of metal are subject to microbiological corrosion, which may cause a decrease in the flow capacity of water pipes. The use of synthetic materials does not fully protect the water supply system against the development of biofilm. Organic compounds used by microorganisms as food substrate are washed away from the surface of polymeric materials. This leads to a significant decrease in the sanitary quality of 
water in consumers. Biofilm developing on smooth surfaces is less bonded to them, which makes it easier to rinse microorganisms out of it into water at increased flow rate[5].

Clear differences in the bacterial community structure between the material removed from plastic and cast iron pipes have been described by Douterelo et al (2014). Spirochaeta spp. was highly abundant in the samples from the polyethylene pipe but not in the ones from the cast iron pipe. In the samples obtained from the material removed from the cast iron pipe section were observed a high presence of bacteria specialised in using iron and manganese compounds such as Lysinibacillus spp., which is naturally present in soils and can oxidise manganese, Geobacillus spp., which can absorb several heavy metals including iron and Magnetobacterium spp., which can accumulate magnetite (iron mineral, $\mathrm{Fe}_{3} \mathrm{O}_{4}$ ) inside their cells [3].

It is very important that corrosive materials and corrosion products consume certain amounts of disinfectants, and by obstructing their access to microorganisms they reduce the effectiveness of deactivation [12]. Biofilm formation (Fig.1) is a multi-stage process, determined on the one hand by the features of the microorganisms forming it and on the other hand by the structure and properties of the colonized materials.

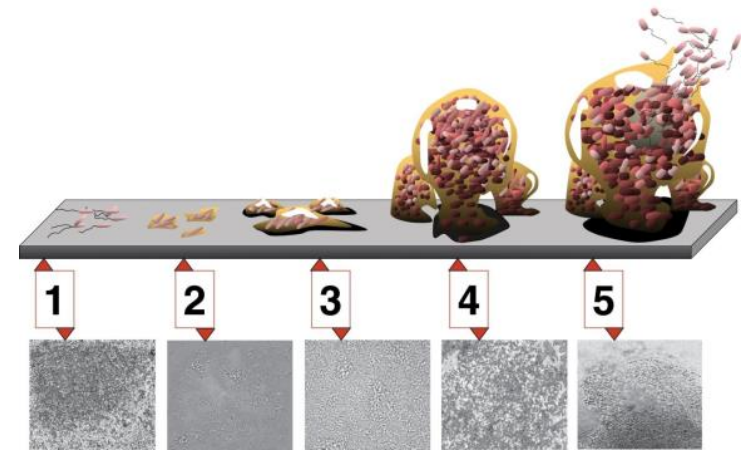

Fig.1 Formation of a mature biofilm [9]

Colonization is also facilitated by the structure of the surface and all its damage and roughness. The mechanism of biofilm formation is not yet well known. Different phases can be observed in the process of its production. Stage 1: initial attachment; stage 2: irreversible attachment; stage 3: maturation I; stage 4: maturation II; stage 5: dispersion [5,9]. 


\section{Stagnation of water}

Water stagnation in water supply network led to changes in water quality parameters. Long residence times which may vary from 2 to 30 days depending on the population size, is known to promote microbial growth in water distribution networks. When it comes to domestic drinking water system, water can further stagnate in pipes for hours, days or even weeks before being consumed [14]. Household pipes can, in fact, have a considerable impact on the water quality, which was already reported as increased concentrations of lead, cadmium, copper and nickel after stagnation in household tap water. In the distribution network, bacterial growth is limited by low nutrient concentrations, disinfectant residuals, low temperatures and short residence times. However, it is possible that the microbial quality may change in household pipes, where higher temperatures, longer residence times, depletion of disinfectant residuals and nutrient contamination from pipe material or from the household environment could lead to bacterial growth. This may cause problems, since bacterial growth can lead to adverse aesthetic changes such as the development of taste, odour and colour in drinking water [8].

\section{MATERIALS AND METHODS}

The aim of the work was to assess the changes of selected physical and chemical parameters of water in the water supply network in Świebodzin. Water samples entering the water supply system and in eight selected control points in the city were taken for analysis (Fig. 2).

The scope of laboratory analysis of water samples taken, includes the determination of parameters:

- Colour - according to Norm PN-EN ISO 7887:2012,

- $\mathrm{pH}$ - according to Norm PN-EN ISO 10523:2012,

- Turbidity - according to Norm PN-EN ISO 7027-1:2016-09,

- $\mathrm{COD}_{\mathrm{Mn}}$ - according to Norm PN-EN ISO 8467:2001,

- Manganese - according to Norm PN-92/C-04590/03,

- Total iron - according to Norm PN-ISO 6332:2001.

Water samples were collected according with the guidelines for the collection of water samples for laboratory tests (PN-ISO 5667-5: 2017-10). 


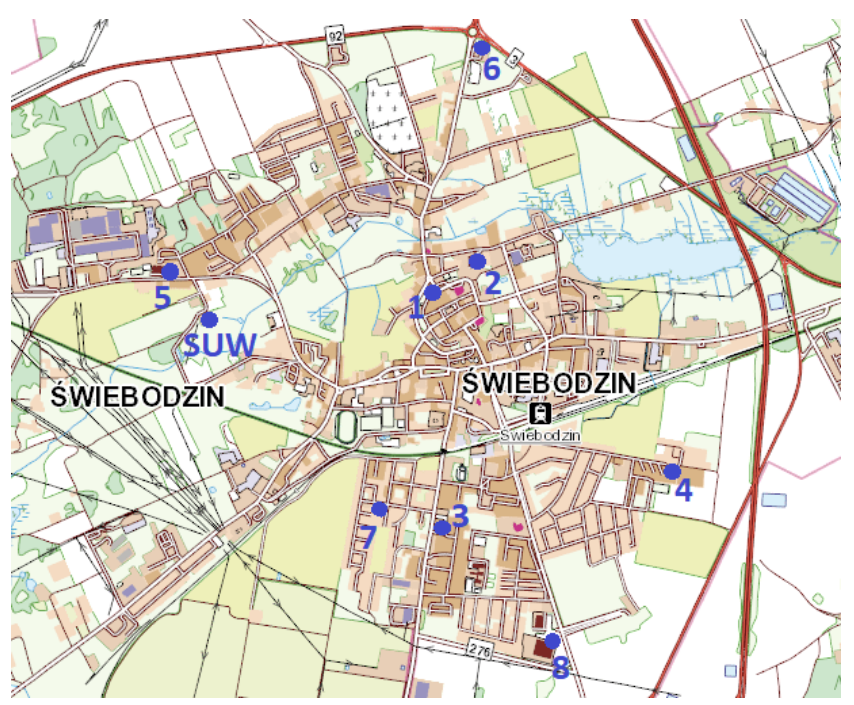

Fig.2 Location of control points in the city

The City of Świebodzin uses the Quaternary groundwater resources exploited by means of 11 drilled wells, the location of which is shown in Figure 2, in order to supply the Municipal Water Supply System. Used wells operate alternately. On average 6-8 wells work per day.



Fig.3 Location of underground water intakes 
The waters of all eleven wells are characterized by a similar physico-chemical and bacteriological composition. The quality of raw water drawn from exploited wells is shown in Table 1 .

Table 1 . The quality of raw underground water

\begin{tabular}{|l|c|c|c|}
\hline \multicolumn{1}{|c|}{ Parameter } & Unit & Raw water & $\begin{array}{c}\text { Parameters of water intended } \\
\text { for human consumption } \\
\text { (Journal of Laws 2017, item 2294) }\end{array}$ \\
\hline Coli group bacteria & $\mathrm{jtk} / 100 \mathrm{ml}$ & 4 & 0 \\
\hline Enterococci & $\mathrm{jtk} / 100 \mathrm{ml}$ & 0 & 0 \\
\hline Escherichia coli & $\mathrm{jtk} / 100 \mathrm{ml}$ & 0 & 0 \\
\hline Taste & - & acceptable & acceptable \\
\hline Smell & - & acceptable & acceptable \\
\hline Total iron & $\mu \mathrm{g} \mathrm{Fe} / \mathrm{dm}^{3}$ & $1,140 \pm 114$ & 200 \\
\hline Manganese & $\mu \mathrm{g} \mathrm{Mn} / \mathrm{dm}^{3}$ & $170 \pm 17$ & 50 \\
\hline Colour & $\mathrm{mg} \mathrm{Pt} / \mathrm{dm}^{3}$ & $10 \pm 5$ & 15 \\
\hline Turbidity & $\mathrm{NTU}$ & $31.3 \pm 4.7$ & 1 \\
\hline pH & - & $7.6 \pm 0.1$ & $6.5-9.5$ \\
\hline Chlorides & $\mathrm{mg} / \mathrm{dm}^{3}$ & $20 \pm 4$ & 250 \\
\hline Sulphate & $\mathrm{mg} / \mathrm{dm}^{3}$ & $71 \pm 14$ & 250 \\
\hline
\end{tabular}

Water from the captured aquifer is characterized by increased iron and manganese content, as well as excessive turbidity and does not meet the requirements for drinking water. The water treatment process is carried out in the following technological sequence (Fig.4):

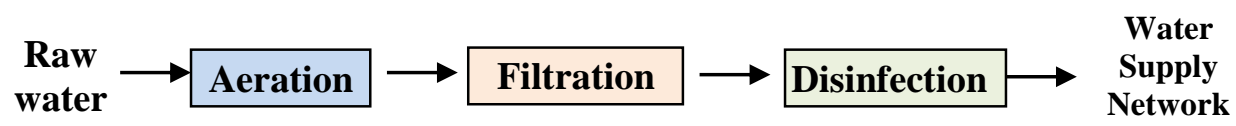

1. Aeration on open drip towers with natural airflow 2. Pressure filtration on a braunzin catalytic bed 3 . Disinfection with $3 \%$ sodium hypochlorite solution.

Fig.4 Technological sequences of water treatment at the WTP in Świebodzin

The length of the city's water supply network is about $122 \mathrm{~km}$ of pipes with diameters in the range of $25-300 \mathrm{~mm}$. Much of the nets in the old parts of the city are made of steel and lead pipes. Both modernised and new sections as well as connections are made of polyethylene. On the network there are located two reserve and equalisation tanks, compensating for unevenness of hourly and daily water intakes. 


\section{RESULTS AND DISCUSSION}

Table 2 presents the results of research on the quality of water parameters in the water supply network in Świebodzin. The parameters of water injected into the water supply network were in accordance with the Regulation of the Minister of Health on the quality of water intended for human consumption (Journal of Laws 2017, item 2294). The average values of indices in the period of the conducted tests were respectively: the colour: $1.5 \mathrm{mgPt} / \mathrm{dm}^{3}$, turbidity $0.39 \mathrm{NTU}$, the total iron $0.008 \mathrm{mgFe} / \mathrm{dm}^{3}, \mathrm{COD}_{\mathrm{Mn}}$ value $0.2 \mathrm{mgO}_{2} / \mathrm{dm}^{3}$, and the $\mathrm{pH}$ ranged from 7.52 to 7.54 .

Table 2. Water parameters at control points in the water supply network

\begin{tabular}{|c|c|c|c|c|c|c|c|c|c|c|}
\hline \multirow{2}{*}{ Parameter } & \multirow{2}{*}{ Unit } & \multicolumn{9}{|c|}{ Control points } \\
\hline & & WTP & P1 & $\mathbf{P 2}$ & $\mathbf{P 3}$ & P4 & P5 & P6 & P7 & $\mathbf{P 8}$ \\
\hline \multicolumn{3}{|c|}{ Distance from the WTP, $\mathrm{km}$} & 1.7 & 2.0 & 2.3 & 3.0 & 0.4 & 2.2 & 2.5 & 3.1 \\
\hline Colour & $\mathrm{mgPt} / \mathrm{dm}^{3}$ & 1.5 & 2.25 & 6.00 & 5.25 & 3.00 & 3.00 & 3.75 & 4.50 & 6.00 \\
\hline $\mathrm{pH}$ & - & $7.52-7.54$ & 7.52 & 7.54 & 7.57 & 7.54 & 7.56 & 7.63 & 7.58 & 7.64 \\
\hline Turbidity & NTU & 0.39 & 0.44 & 1.5 & 1.09 & 0.59 & 0.47 & 0.66 & 0.48 & 1.26 \\
\hline $\mathrm{COD}_{\mathrm{Mn}}$ & $\mathrm{mgO}_{2} / \mathrm{dm}^{3}$ & 0.2 & 0.2 & 0.3 & 0.3 & 0.4 & 0.3 & 0.9 & 0.5 & 1.1 \\
\hline Manganese & $\mathrm{mgMn} / \mathrm{dm}^{3}$ & $<0.05$ & $<0.05$ & $<0.05$ & $<0.05$ & $<0.05$ & $<0.05$ & $<0.05$ & $<0.05$ & $<0.05$ \\
\hline Total iron & $\mathrm{mgFe} / \mathrm{dm}^{3}$ & 0.008 & 0.033 & 0.149 & 0.084 & 0.047 & 0.009 & 0.086 & 0.047 & 0.087 \\
\hline
\end{tabular}

The studies showed that the water parameters in the water supply network changed. The biggest changes were noted in the case of turbidity, colour and total iron (Fig. 5).

The presented data show that, at points $2 \mathrm{~km}$ or more away from WTP, the value of controlled water indicators was significantly higher than at points less distant. $\mathrm{pH}$ of water in the network increased and the highest values were recorded in P6 and $\mathrm{P} 7$ respectively 7.63 and 7.64. $\mathrm{COD}_{\mathrm{Mn}}$ ranged from $0.3 \mathrm{mg} / \mathrm{dm}^{3}$ (P5) to $1.1 \mathrm{mg} / \mathrm{dm}^{3}$ (P8) with an initial value of $0.2 \mathrm{mg} / \mathrm{dm}^{3}$ at the outlet of the Water Treatment Plant. The turbidity varied from 0.44 NTU (P1) to 1.5 NTU (P2) with an initial value of $0.39 \mathrm{NTU}$ in water injected into the network. At three control points, the permissible turbidity level of 1 NTU was exceeded. Water colour varied from $2.25 \mathrm{mgPt} / \mathrm{dm}^{3}$ (P1) to $6.00 \mathrm{mgPt} / \mathrm{dm}^{3}$ (P2 and P8), i.e. an increase of 16 to $173 \%$. The highest iron concentration was recorded in P2 and was $0.149 \mathrm{mg} / \mathrm{dm}^{3}$. At none of the measurement points, the admissible value was exceeded, while the concentration of iron in the network was 5 to 16.5 times higher than its value in water flowing out of WTP. 


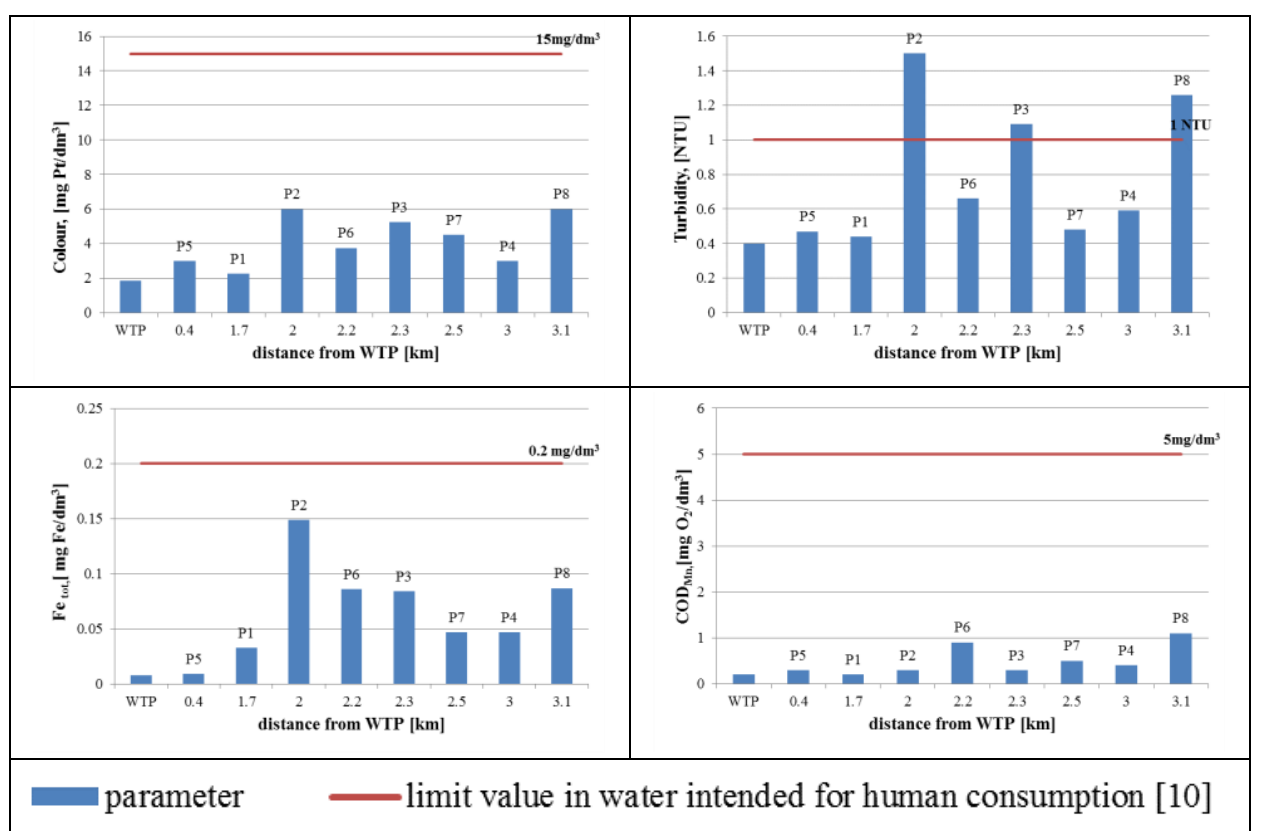

Fig. 5Water parameters in the water supply network

The analysis of the results showed that the increase in turbidity and colour of water depended on the increase in total iron concentration (Fig.6). Turbidity gain and coloration describe equations:

Turbidity $=8.155\left[\mathrm{Fe}_{\mathrm{og}}\right]+0.2672$ and Colour $=28.998\left[\mathrm{Fe}_{\mathrm{og}}\right]+2.1863$.

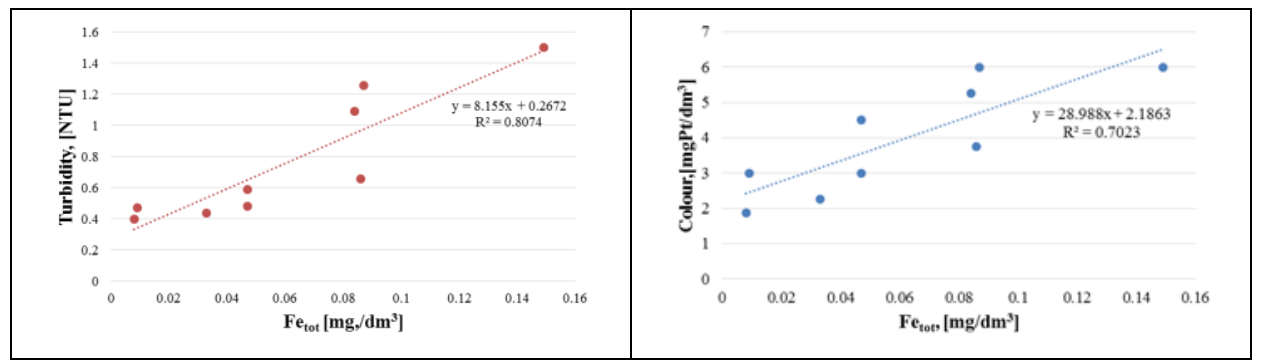

Fig. 6 Dependence of turbidity and colour increase on total iron concentration

The study confirmed that the reason for the deterioration of the quality of water in the grid and in household connections is the unfavourable material structure. The highest increase in the examined water parameters and in the case of turbidity, exceeding the limit value for water intended for consumption was found in P2, P3 and P8, located on a network made of steel pipes. 
An increase in water parameters characteristic for points at the ends of the network (P4 and P8) as a result of stagnation in ducts was also demonstrated. The differences in water quality result from the materials used for the pipelines. At point $\mathrm{P} 4$ (polyethylene pipeline), the increase in turbidity, colour, iron and $\mathrm{COD}_{\mathrm{Mn}}$ was smaller, and the water did not lose its nutritional value.

\section{CONCLUSIONS}

On the basis of preliminary research, it was shown that water parameters in the water supply system of Świebodzin city differ from their values in water coming out of the Water Treatment Plant. The obtained results concerning the content in water of total iron and related turbidity and colour indicate the chemical instability of water in the water distribution system.

In the case of turbidity, the limit value for water intended for consumption was exceeded. Secondary water pollution depends both on the type of material of the network or connection and on the distance from the Water Treatment Plant. Higher concentrations of pollutants were found in steel pipelines than in polyethylene and at points $2 \mathrm{~km}$ or more away from WTP.

\section{REFERENCES}

1. Boryczko K., Tchórzewska-Cieślak B.: Analysis of risk of failure in water main pipe network and of delivering poor quality water, Environment Protection Engineering 40,4 (2014) DOI: 10.5277/epe140407.

2. Chudzicki J., Kwietniewski M., Iwanek M., Suchorab P.: Secondary contamination in Polish drinking water, WIT Transactions on The Built Environment, Vol 139 (2014) www.witpress.com, ISSN 1743-3509 (on-line) DOI:10.2495/UW140021.

3. Douterelo I., Husband S., Boxall J.B.: The bacteriological composition of biomass recovered by flushing an operational drinking water distribution system, Water Research 54 (2014) 100-114.

4. Jachimowski A.: Factors affecting water quality in a water supply network, Journal of Ecological Engineering 18,4 (2017) 110-117, DOI:10.12911/22998993/74288.

5. Kołwzan B.: Analiza zjawiska biofilmu - warunki jego powstawania $i$ funkcjonowania, Ochrona Środowiska, 33,4 (2011) 3-14.

6. Kowal A.,: Przyczyny i zapobieganie zmianom jakości wody $w$ systemach wodociagowych, Ochrona Środowiska, 25,4 (2003) 3-6.

7. Krupińska I.: Suitability of coagulation for treatment of groundwater Rocznik Ochrona Środowiska, 14 (2012) 491-501 
8. Lautenschlager K., Boon N., Wang Y., Egli T.,Hammes F.: Overnight stagnation of drinking water in household taps induces microbial growth and changes in community composition, Water Research 44 (2010) 4868-4877.

9. Monroe D.: Looking for chinks in the armor of bacterial biofilms. PLoS Biol. 2007 Nov; 5(11):e 307.

10. Regulation of the Minister of Health on quality requirements for water intended for human consumption, Journal of Laws 2017 item 2294.

11. Świderska-Bróż M., Wolska M.,: Glówne przyczyny wtórnego zanieczyszczenia wody w systemie dystrybucji, Ochrona Środowiska, 28,4 (2006) 29-34.

12. Świderska-Bróż M.: Czynniki wspótdecydujące o potencjale powstawania i rozwoju biofilmu w systemach dystrybucji wody, Ochrona Środowiska, 32,3 (2010) 1-7.

13. Water safety in distribution systems. Printed by the WHO Document Production Services, Geneva, Switzerland 2014.

14. Zlatanovic Lj., J.P. van der Hoek,Vreeburg J.H.G.:An experimental study on the influence of water stagnation andtemperature change on water quality in a full-scale domestic drinking water system, Wat. Res. 123 (2017) 761-772.

\section{STABILOŚĆ CHEMICZNA WODY W SIECI WODOCIĄGOWEJ - BADANIA WSTEPNE}

Streszczenie

Prawidłowo działający system dystrybucji wody pitnej powinien zapewnić nie tylko właściwe parametry jakości wody wprowadzanej do sieci wodociągowej, ale przede wszystkim u odbiorców. Zbyt mało uwagi poświęconej właściwemu zarządzaniu systemami dystrybucyjnymi stwarza wiele zagrożeń sprzyjających wtórnemu zanieczyszczeniu wody w czasie jej przesyłu do odbiorców. Utrzymanie bezpieczeństwa sanitarnego wody i zapobieganie jej zanieczyszczeniu w systemie dystrybucji jest obecnie jednym z głównych celów Światowej Organizacji Zdrowia. W artykule przedstawiono wyniki badań dotyczące zmian wybranych parametrów wody w sieci wodociągowej miasta liczącego 22 tys. mieszkańców. Parametry wody w sieci kontrolowano w 8 punktach, oddalonych od Stacji Uzdatniania Wody od 0,4 do 3,1 km. Lokalizację punktów kontrolnych wytypowano tak, aby ocenić jakość wody w zależności od materiału rur oraz w punktach niekorzystnych - na końcówkach sieci. Wykazano, że w efekcie wtórnego zanieczyszczenia wody następuje wzrost mętności, barwy i żelaza ogólnego. Na końcówkach sieci parametry wody były podwyższone i przekraczały wartości dopuszczalne.

Keywords in Polish wtórne zanieczyszczenie wody w sieci wodociągowej, system dystrybucji wody, jakość wody

Editor received the manuscript 12.06.2018 